\title{
EVALUATION OF SPEED AND DURATION OF EFFICACY OF SPINOSAD TABLETS FOR TREATMENT AND CONTROL of Ctenocephalides canis (Siphonaptera: Pulicidae) infestations in dogs
}

\author{
FRANC M.* \& BOUHSIRA E.*
}

\section{Summary :}

A controlled clinical trial was performed to determine the duration of efficacy of a new oral insecticide formulation of spinosad for the control of experimentally induced Ctenocephalides canis infestations in dogs. Twelve Beagle dogs (two groups of six) were used in the study. Dogs in the treated group received spinosad tablets per os on DO at the commercial dosage. All dogs were infested with 100 fleas on Days $-7,-1,7,14,21,28$ and 35. The dogs were combed four hours after each infestation and fleas were counted and replaced on the coat. 24 hours after each infestation fleas were combed, counted and removed. The efficacy of the formulation was calculated four and 24 hours after the treatment and then four and 24 hours after each new infestation. The mean number of fleas on the control dogs was respectively between 65.1 and 83.3 at four hour counts and between 58.3 and 75.3 at 24 hour counts. The product was well tolerated. The treatment controlled the fleas already present on the skin with $81 \%$ efficacy at four hours and $100 \%$ efficacy at 24 hours. For the weekly infestations, the speed of action of the product was high: at four hours the efficacy was $100 \%$ at D7, $96 \%$ at D14, $74 \%$ at D21, $42 \%$ at D28, $12.90 \%$ at D35 and $12.8 \%$ at D42. The efficacy evaluated 24 hours after each infestation was approximately $100 \%$ during three weeks then $90 \%$ at D39, $81.4 \%$ at D36 and $80.4 \%$ at D43. A single dose of the new spinosad tablet formulation should control flea populations in dogs for four weeks as indicated in the claim (evaluation performed at $48 \mathrm{~h}$ for the registration). Spinosad tablet is the first product administered per os which acts so long and so quickly against adult fleas.

KEY WORDS : Ctenocephalides canis, control, spinosad, oral tablets, dogs.

MOTS CLÉS : Ctenocephalides canis, contrôle, spinosad, formulation orale, chien.

\section{INTRODUCTION}

pinosad is a macrocyclic lactone derived from the $\circlearrowleft$ fungus Saccharopolyspora spinosa (Mertz \& Yao, 1990) The two most abundant components produced from fermentation of S. spinosa are spinosyns A and D (Fig. 1), which are the major active components of the flea product spinosad (Kirst et al., 2002). This

* UMR 181, École Nationale Vétérinaire de Toulouse, 23, Chemin des Capelles, 31076 Toulouse Cedex France.

Correspondence : Michel Franc.

Tel.: + 33 (0)5 61193873 - Fax: + $33(0) 561193971$.

E-mail: m.franc@envt.fr
Résumé : ÉVAluation de la RAPIDITÉ ET DE LA DURÉE D’EFFiCACITÉ DE SPINOSAD PER OS DANS LE TRAITEMENT ET LE CONTRÔLE DE L'INFESTATION EXPÉRIMENTALE DE CHIENS PAR CTENOCEPHALIDES CANIS (Siphonaptera: Pulicidae)

Cet essai clinique a été réalisé dans le but de déterminer la durée de l'efficacité d'une nouvelle formulation orale à base de spinosad dans le contrôle d'infestation de puces Ctenocephalides canis expérimentalement induite chez le chien. Douze Beagle /deux groupes de six) ont été utilisés dans cette étude. Les chiens du groupe traité ont reçu per os à 10 un comprimé de spinosad à la posologie recommandée par le laboratoire. Tous les chiens ont été infestés avec 100 puces à ] - 8, J - 1, J7, J14, J21, J28 et 335. Les chiens ont été peignés quatre heures après le traitement ainsi qu'à chaque nouvelle infestation, les puces ont été comptées et replacées sur le pelage. 24 heures après chaque infestation les chiens étaient peignés et les puces comptées et éliminées. L'efficacité de la formulation a été calculée quatre heures et 24 heures après le traitement, puis quatre heures et 24 heures après chaque infestation. Le nombre moyen de puces sur les chiens témoins était compris entre 65,1 et 83,3 quatre heures après chaque infestation et entre 58,3 et 75,3 24 heures après. Le produit a été bien toléré. Le traitement élimine les puces présentes dans le pelage avec 81 \% d'efficacité en quatre heures et $100 \%$ d'efficacité en 24 heures. La rapidité d'action du produit est élevée: au bout de quatre heures, les puces sont détruites avec une efficacité de $100 \%$ (J7), $96 \%$ (U14), $74 \%$ (V21), $42 \%(V 28), 12,90 \%$ (J35) et de 12,8\% (J42). L'efficacité évaluée 24 heures après chaque infestation est d'environ $100 \%$ pendant trois semaines puis de $90 \%$ (J39), $81,4 \%$ (J36) et de $80,4 \%$ (J43). Une dose unique de la formulation de spinosad permet de contrôler les populations de puces chez le chien pendant quatre semaines, comme il est précisé dans l'indication (évaluation effectuée à 48 h). Le comprimé contenant du spinosad est le premier produit administré par voie orale qui agit aussi

longtemps et si rapidement sur les puces adultes. 
insecticide is largely used in agriculture to control insects and mites. Some publications report the activity of the product on mosquitoes (Cetin et al., 2005), Musca domestica (Kristensen et al., 2004) and tsetse fly (De Deken et al., 2004). Two publications report the efficacy of the product on Ctenocephalides felis when administered monthly at a mean dose of $30 \mathrm{mg} / \mathrm{kg}$ (Snyder et al., 2007; Roberston-Plouch et al., 2008)

The purpose of this study was to determine the duration of efficacy of a new formulation (spinosad tablets, ComfortisTM $^{\circledR}$, Lilly Elanco) in the control of experimental infestations of adult fleas Ctenocephalides canis (Siphonaptera: Pulicidae) (Curtis, 1826) when administered once orally to Beagle dogs at the Laboratory recommended dosage (over $30 \mathrm{mg} / \mathrm{kg}$ ).

\section{MATERIALS AND METHODS}

\section{Dogs}

T $\checkmark$ welve adult beagle dogs of three-years-old, weighing from 8.6 to $12.5 \mathrm{~kg}$, were used in this study. Each dog was housed in an individual stainless steel cage in an environmentally controlled room and was allowed spending six hours a day in an exercise area without contact with the other dogs. They were fed with a dry ration (Royal Canin ${ }^{\circledR}$ medium adult), and water was available ad libitum.

After a 9-day acclimatization period and before treatment they were challenged with 100 unfed Ctenocephalides canis to check their sensitivity to fleas. Then they were randomly allocated into two groups of six (group A-control and group B-treated). None of the dogs had received any antiparasitic treatment which has ectoparasiticidal activity within two months before the start of acclimatization.

Clinical observations of each dog were carefully carried out daily throughout the study.

\section{FLEAS MAINTENANCE AND SUPPLY}

The strain of Ctenocephalides canis originated from a wild strain, harvested from dogs in Montesquieu-Volvestre (F-31330, south of France) and had been maintained on dogs at the laboratory since April 2008.

Experimental procedure

. Experimental infestation

For each experimental infestation, 100 unfed, young adult fleas (males and females) were placed along each dog's dorsal midline. The dogs were infested with the same numbers of fleas seven days and one day before the treatment then $7,14,21,28,35$ and 42 days after the treatment. D0 is the treatment day.

\begin{tabular}{ccc}
\hline Animal ID & Weight $(\mathbf{k g})$ & Dose $(\mathbf{m g} / \mathbf{k g})$ \\
\hline 2619 & 11.33 & 49,43 \\
2870 & 10.33 & 54.21 \\
3495 & 12.07 & 46.40 \\
2819 & 8.53 & 31.65 \\
2698 & 10.32 & 54.26 \\
2715 & 10.21 & 54.85 \\
\hline
\end{tabular}

Table I. - Doses of spinosad administered per dog.

- Flea counting procedure

Fleas were counted by carefully combing the entire coat of each dog, which was performed by two technicians during 10 minutes, using a fine-toothed comb. If no flea was collected during the last minute the combing was stopped. If not, the dog was combed until no flea was collected during a period of one minute. Collected fleas were counted and replaced on each dog at four hour counts after the treatment or four hours after each new infestation, when collected 24 hours after the treatment or after each new infestation, the fleas were removed. Dogs were combed on days: 0, 7, 14, 21, 28, 35 and 42.

\section{. Treatment}

Dogs of group A were not treated (control group).

Dogs of group B were treated with flavoured tablets containing 270 or $560 \mathrm{mg}$ of spinosad (10.1-20 lbs or 20.1-40 lbs, depending on the weight of the dogs, following the Laboratory recommendations). Using the tablets, the mean dose was $48.5 \mathrm{mg} / \mathrm{kg}$ (S.D. $8.9 \mathrm{mg} / \mathrm{kg}$ ) administered once per os on Day 0.The doses of spinosad ranged from 31.65 to $54.85 \mathrm{mg} / \mathrm{kg}$ (Table I). The administration of the tablet was performed during the meal.

\section{DATA ANALYSIS}

Effectiveness was calculated by comparing the arithmetic mean of fleas counted on treated dogs with the one counted on control dogs, using the following formula:

$\%$ of effectiveness $=100\left(\mathrm{~N}^{\mathrm{C}}-\mathrm{N}^{\mathrm{t}}\right) / \mathrm{N}^{\mathrm{C}}$

$\mathrm{N}^{\mathrm{C}}=$ mean Number of fleas on control dogs

$\mathrm{N}^{\mathrm{t}}=$ mean Number of fleas on treated dogs

Statistical analyses: data were analysed by the general linear model (GLM) of Systat (u.g, SPSS, 1998) using repeated measures procedure. In a second step, groups were compared date by date by use of Student's t-test.

\section{RESULTS}

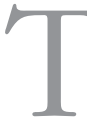
The drug was well tolerated. No adverse reaction as vomiting has been observed after oral administration. 
SPEED OF ACTION OF SPINOSAD EVALUATED AT FOUR HOURS

The mean number of fleas collected on the dogs and the Standard deviation for the two groups are reported on the Figure 2. Overall using the GLM analysis, significant difference was found between the two groups $(\mathrm{p}<0.001)$. The date-by-date analysis reported significantly different values until day 35 ( $\mathrm{p}<0.01$ from D0 to D28, difference was significant $(\mathrm{p}<0.05)$ at day 35), and on day 42 no significant was shown.

Four hours after the treatment the efficacy was about $81 \%$ and fleas were found on only one dog out of the six treated. The efficacy at four hours after weekly infestations remained over $95 \%$ for two weeks, and then decreased quickly (Table II).

\section{Evolution of mean fleas at $4 \mathrm{~h}$}

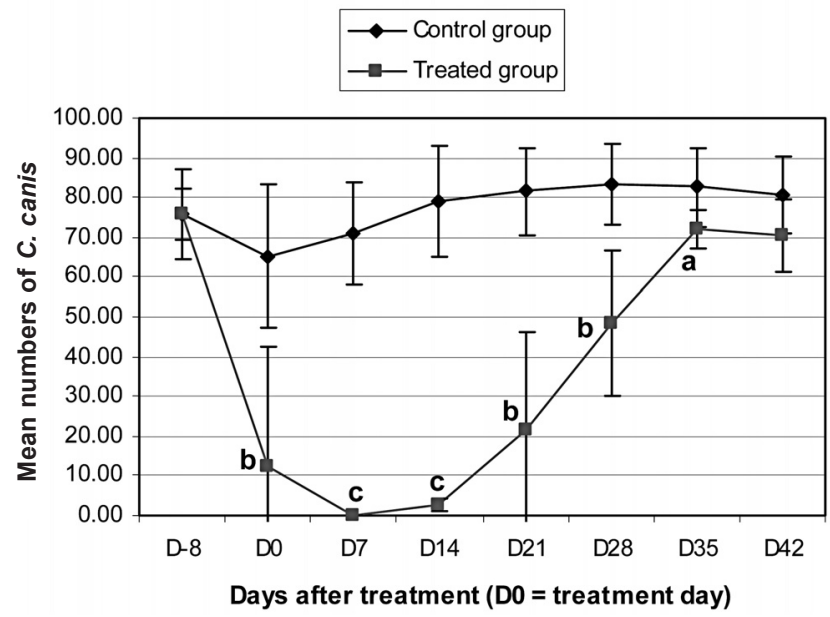

Fig. 2. - Mean (sd) Ctenocephalides canis counts four hours after treatment with spinosad formulation realised on D0 and four hours after each reinfestation with 100 adult $C$. canis. a: $\mathrm{p}<0.05$; b: $\mathrm{p}<$ $0.01 ; \mathrm{c}: \mathrm{p}<0.001$.

\begin{tabular}{lccccccc}
\hline & \multicolumn{7}{c}{ Days after treatment } \\
\cline { 2 - 8 } & D0 & D7 & D14 & D21 & D28 & D35 & D42 \\
\hline \% efficacy & 81.07 & 100 & 96.62 & 73.67 & 41.8 & 12.90 & 12.81 \\
\hline
\end{tabular}

Table II. - Efficacy (\%) of spinosad tablets administered to dogs experimentally infested with Ctenocephalides canis, calculated four hours after the treatment (D0) and four hours after each reinfestation.

\section{ACTIVITY AgAinst $C$. CANIS EVALUATED AT 24 HOURS}

The mean number of fleas found on the control dogs 24 hours after each flea deposition ranged between 58.3 and 75.3 (Fig. 3). Overall using the GLM analysis, significant difference was found between the two groups $(p<0.001)$. The date-by-date analysis reported significantly different values $(p<0.01)$ from D0 to Day 43.

\section{Evolution of mean fleas at $24 \mathrm{~h}$}

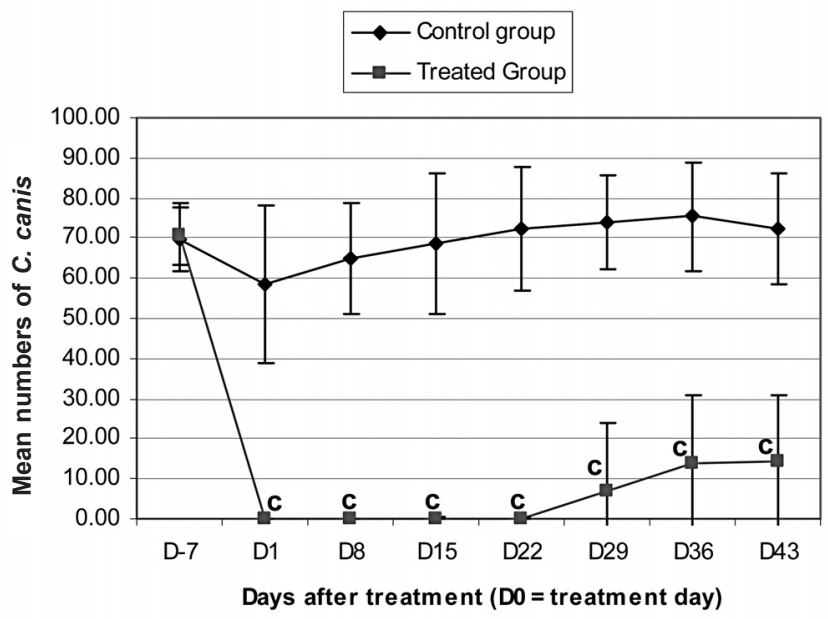

Fig. 3. - Mean (sd) Ctenocephalides canis counts 24 hours after treatment with spinosad formulation performed on D0 and 24 hours after each reinfestation with 100 adult fleas. c: $\mathrm{p}<0.001$

The administration of spinosad tablets had eradicated the fleas from all the dogs when they were examined 24 hours after the treatment. The product protected dogs from the reinfestations with C. canis for three weeks with an efficacy higher than $99 \%$ which remains at $90 \% 30$ days after the treatment (Table III). Then the efficacy decreases to approximately $80 \%$ at Day 36 and Day 43.

\begin{tabular}{lccccccc}
\hline & \multicolumn{7}{c}{ Days after treatment } \\
\cline { 2 - 8 } & D1 & D8 & D15 & D22 & D29 & D36 & D43 \\
\hline \% efficacy & 100 & 100 & 99.76 & 99.77 & 90.29 & 81.42 & 80.41 \\
\hline
\end{tabular}

Table III. - Efficacy (\%) of spinosad tablets administered to dogs experimentally infested with Ctenocephalides canis, calculated 24 hours after the treatment and 24 hours after each reinfestation.

\section{DISCUSSION AND CONCLUSION}

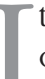
$\mathrm{t}$ is the first publication which reports the efficacy of spinosad on Ctenocephalides canis. This trial demonstrates that spinosad acts quickly (four hours) during two weeks after its administration at a posology of $30 \mathrm{mg} / \mathrm{kg}$ or more. If evaluated at 24 hours, the efficacy is approximately $100 \%$ during three weeks and approximately $90 \%$ after one month. These results are in accordance with those published by Snyder et al. (2007) who obtained 97.2 to $100 \%$ efficacy on C. felis (flea counts performed 48 hours post-infestation). These informations are useful for the practitioner. During three weeks after the administration of spinosad at the commercial dosage the fleas will stay alive during only four hours before they die. The limitation 
of biting will be interesting in the control of the flea allergy dermatitis.

Nitenpyram (Capstar ${ }^{\circledR}$, Novartis) is also a fast acting orally administered flea treatment, but its administration provides an effective mechanism to eliminate adult fleas from hosts for only up to 48 hours after treatment (Rust et al., 2003). Spinosad tablet is the first product administered per os which act so long against adult C. canis. Furthermore oral formulations may be preferred by some pet owners to avoid the presence of insecticide on the hair and in the environment.

\section{ACKNOWLEDGEMENTS}

The authors thank Mr Francis Enjalbert for the statistical help, Mrs Martine Roques, Solange Vermot and Sonia Gounaud for their assistance.

\section{REFERENCES}

Cetin H., Yanicoglu A. \& Cilek J.E. Evaluation of the naturally-derivated insecticide spinosad against Culex pipiens (Diptera: Culicidae) larvae in septic tank water in Antalya, Turkey. Journal of Vector Ecology, 2005, 30 (1), 151-154.

De Deken R., Speybroeck N., Gillain G., Sique H., Batawi K. \& VAN Den Bossche P. The macrocyclic lactone "spinosad", a promising insecticide for tsetse fly control. Journal of Medical Entomoly, 2004, 41 (5), 814-818.

Kirst H.A., Creemer L.C., Naylor S.A., Pugh P.T., Snyder D.E., Winkle J.R., Lowe L.B., Rothwell J.T., Sparks T.C. \& Worden T.V. Evaluation and development of spinosyns to control ectoparasites on cattle and sheep. Current Topics in Medicinal Chemistry, 2002, 2, 675-699.

KRISTENSEN M. \& JesPersen J.B. Susceptibility of spinosad in Musca domestica (Diptera: Muscidae) field populations. Journal of Economic Entomology, 2004, 97 (3), 1024-1028.

MerTz H. \& YAO R.C. Saccharopolyspora spinosa sp. nov. isolated from soil collected in a sugar mill rum still. International Journal of systematic Bacteriology, 1990, 40, 34-39.

Robertson-Plouch C., Baker K.A., Hozak R.R., ZImmermann A.G., Parks S.C., Herr C., Jay J., Hutchens D.E. \& Snyder D.E. Clinical field study of the safety and efficacy of spinosad chewable tablets for controlling fleas on dogs. Veterinary therapeutics, 2008, 9 (1), 26-36.

Rust M.K., Waggoner M.M., Hinkle N.C., STAnsfield D. \& BarNETT S. Efficacy and longevity of nitenpyram against adult cat fleas (Siphonaptera: Pulicidae). Journal of medical entomology, 2003, 40 (5), 678-681.

Snyder D.E., Meyer J., Zimmermann AG., QiaO M., Gissendanner S.J., Cruthers L.R., Slone R.L. \& Young D.R. Preliminary studies of the effectiveness of the novel pulicide, spinosad, for the treatment and control of fleas on dogs. Veterinary parasitology, 2007, 150 (4), 345-351. 